\title{
“Lock This Whore Up": Legal Violence and Flows of Information Precipitating Personal Violence against People Criminalised for HIV-Related Crimes in Canada
}

\author{
Alexander MCCLELLAND*
}

This article examines the convergence of myriad forms of information on people who come to be targets of state and public control due to the perceived risk they present through having been alleged to have not disclosed their HIV-positive status to sex partners. Attending to the material, violent impacts of criminalisation - violence, both legal and extralegal - this article outlines how punishment is enhanced and amplified through the flow of information. Focusing on the material impacts of flows of information about the daily lives of people who face criminalisation moves analysis beyond solely a theoretical object of inquiry and helps to frame an understand that the effects of big data operate not just "within" big data surveillance, but also "beyond" big data surveillance.

\section{INTRODUCTION}

This article examines the convergence of myriad forms of information on people who come to be targets of state and public control due to the perceived risk they present through having been alleged to have not disclosed their HIV-positive status to sex partners. When a person is marked as a criminal and a threat to public safety, a wide range of information is produced from authoritative institutions of policing, media, public health and criminal justice, and proliferates about the person and their case, such as press releases, legal case documents, media articles and interviews, personal photographs, institutional directives, expert opinions, medical files, social media and bulletin board posts, police communications and interviews. These forms of information and the ways in which they proliferate in the public sphere are not benign. Rather, information can be dispersed and mobilised to discriminate against people, to enhance their surveillance, to be predictive of perceived future risks, and to regulate and circumscribe behaviour and opportunities. This convergence of information, and the ways in which it can be taken up, and is socially activated, can help enact forms of violence in the service of punishment and retribution outside of legal forms of violence.

* Centre for Interdisciplinary Studies in Society and Culture, Concordia University, Montreal, Canada. 
This convergence of forms of information thus reinforces and amplifies legal forms of violence.

Reporting on work within a larger project on what it means to live in "a negative relation to the law", ${ }^{1}$ this article interrogates social sorting processes that effectively banish people of colour, people in poverty, queers, and people generally deemed deviant to the margins of social life. As American legal philosopher Colin Dayan notes, living in a negative relation to the law is tantamount to having one's personhood deconstituted and rendered civilly and socially dead. Legal protections granted to those living in a positive relation to the law are stripped away from those in a negative relation to the law through forms of state-sanctioned violence, surveillance and incapacitation. This situation extends the power of colonisation, white supremacy, misogyny, and homophobia among other forms of marginalisation and oppression. Once people are forced to live in a negative relation to the law, they can become subject to a wide range of extralegal violence, discrimination, and invasive surveillance that exists in legal grey areas. Due to no longer being regarded as a person who is protected under legal regimes, people who live in a negative relation to the law are under threat: they are over-policed and under-protected, and surveilled in their communities. These are people who live in a context where information about them is collected, exposed, dispersed, and mobilised to incapacitate their bodies, and circumscribe their life chances and opportunities.

In this article, I take the criminalisation of HIV non-disclosure, a relatively new and decidedly harsh form of criminalisation - as will be elaborated - as a site from which to explore the material impacts of being marked a criminal and a risk to public safety. Specifically, I examine the role played by forms of information, and how they are deployed, mobilised and socially activated, in practices of legal and extralegal punishment. This is a form of criminalisation that is currently under very active scrutiny and contestation, as it is questionable whether the people who come to be targets of criminal sanction have done any violence themselves, or whether they are merely caught up in a web of HIV-related stigma, fear and AIDS-phobia. For many years, multiple activist groups have mobilised to push to reform the approach. Canadian and international medical professionals and scientists have called for change. ${ }^{2}$ In 2017 , the Canadian Minister of Health publicly stated the legal approach was flawed and in need of reform. ${ }^{3}$ Using this site of contested and in-flux criminalisation helps to highlight an understanding of "the law", as elaborated by Rose and Valverde, not as a "unified phenomenon governed by certain principles", 4 but rather a social, political, economic discursive construction that is applied in order to regulate aspects of society at specific moments in time. This critical approach proposes to analyse how a given population or issue becomes the target of governance, and to then examine how that is taken up by the

\footnotetext{
1 C Dayan, The Law is a White Dog: How Legal Rituals Make and Unmake Persons (Princeton University Press 2011).

2 M Loufty et al "Canadian Consensus Statement on HIV and its Transmission in the Context of Criminal Law" (2014) Canadian Journal of Infectious Diseases and Medical Microbiology 135.

3 Department of Justice, "Minister Wilson-Raybould Issues Statement on World AIDS Day" (1 December 2016), available at <www.marketwired.com/press-release/minister-wilson-raybould-issues-statement-on-world-aids-day2180250.htm > accessed 1 April 2019.

4 N Rose and M Valverde, "Governed by law?" (1998) Social and Legal Studies 569, 545.
} 
various legal, state and extrastate institutions and actors. Understanding legal instruments, practices and processes in this way results in an outcome that views these categories as constructions that need to be continually interrogated, in which the state's definitions of normal and deviant are outcomes of a diverse range of social and historical processes that are subject to change and open to challenge.

In what follows, I will examine the lived experiences of four people who faced criminal charges for allegedly not disclosing their HIV-positive status to sex partners. I consider a number of concepts that help to elaborate the material impacts of criminalisation. First, I detail the legal regime in Canada, followed by a discussion of my critical ethnographic approach. I close the article with a series of reflections on how flows of information can intensify surveillance and punishment of criminalised people. Although the information flows described in this article do not all necessarily emanate from "big data surveillance" in the technical sense of that term, they amount to an assemblage of data-mediated risk management practices and effects, which expresses similar kinds of discriminatory effects to those that are apparent within some big data surveillance systems. We should therefore understand that the effects of big data operate not just "within" big data surveillance, but also "beyond" big data surveillance. To emphasise the consequences of these effects, this article focuses on their lived and embodied experiences.

\section{Context}

As of $2015,{ }^{5}$ over 75,000 people were living with HIV in Canada, with approximately 2,500 new infections each year. The country has concentrated HIV epidemics among subsets of the population, primarily among gay men and other men who have sex with men, Black, Indigenous people, and people who inject drugs. The expansion of legal governance of HIV is an ongoing trend in Canada - only outpaced by the USA and Russia, where in Canada there have been upwards of 200 criminal law cases since 1989 related to exposure or non-disclosure of HIV. ${ }^{6}$ Canada has one federal Criminal Code that each province is tasked with administering, where general criminal laws apply to cases of HIV non-disclosure and exposure. The criminal charge most often applied is aggravated sexual assault, with up to a life-time sentence of incarceration with no chance of parole for 25 years. Charges do not require HIV transmission to occur, and in a majority of the cases the defendant is HIV-negative. Those prosecuted face very long sentences, are registered as sex offenders, and can be held in administrative segregation, which means 23.5 hours a day in a cell alone. The phenomenon is highly racialized, with a disproportionate number of Black and Indigenous people being targeted. ${ }^{7}$ In such cases of either exposure (spitting or biting) or non-disclosure (not telling a sex partner one's HIV-positive status), people's photographs are plastered across media outlets via police press releases prior to a conviction with sensationalised headlines condemning the

5 Public Health Agency of Canada, "Summary: Estimates of HIV Incidence, Prevalence and Proportion Undiagnosed in Canada, 2014" (Surveillance and Epidemiology Division, Public Health Agency of Canada 2015).

${ }^{6}$ C Hastings et al, "HIV Criminalisation in Canada: Key Trends and Patterns" (Canadian HIV/AIDS Legal Network 2017).

7 ibid. 
person with HIV as a criminal, vector of disease and dangerous, reckless and irresponsible person. ${ }^{8}$ As a relatively newer, and decidedly controversial form of criminalisation, HIV-related crimes take place within an active and ongoing site of influx and contested terrain. Since 2012, a landmark Supreme Court decision has guided the application of the law stating that people were obliged to tell a partner they have HIV before they engage in sex that poses a "realistic possibility" of transmission. ${ }^{9}$ The legal test required sex with a condom, and the person with HIV must have a low viral load. In the absence of both using a condom and having a low viral load, or disclosing one's serostatus, a consensual sex act was then re-interpreted by the criminal law as a nonconsensual sex act. Consent under these conditions is presumed by the courts to have been "vitiated". ${ }^{10}$ Sex then becomes constituted as fraudulent and is equated with an aggravated sexual assault. Under this application of the law people had been imprisoned when they were uninfectious due to effective anti-HIV medications and when there was no transmission of HIV. The validity of the 2012 decision has been challenged by some lower courts, in some cases making solely undetectable viral load grounds for dismissing criminal charges. The province of Ontario no longer pursues charges if a person has a supressed viral load. Additionally, in 2018, the Federal Attorney General announced a new federal directive to federal prosecutors who will be no longer able to pursue charges in cases of HIV non-disclosure where a person has maintained a suppressed viral load for more than six months, and generally where a person engaged in only oral sex, or when condoms were used during sex, or when a person was taking treatment prescribed by their doctor.

As well as criminal law, provincial public health laws can also apply. One example is Ontario, Canada's most populous province, which has the highest concentration of people living with HIV, and the highest number of prosecutions for HIV non-disclosure and exposure. Ontario is also the only known place in the world to convict someone of first-degree murder for alleged HIV transmission. Historically, the province is known for having a coercive public health legislative framework that can enable powers very similar to that of the criminal law. This framework is the Ontario Health Promotion and Protection Act, and under s 22 of that Act, a Medical Officer of Health can issue a written order that may require a person to take, or to refrain from taking, specific actions - such as requiring condom use and mandated adherence to medication. The orders are often delivered in person by a public health nurse who also provides a form of counselling around the contents of the order, which are enforced with a $\$ 5,000$ a day fine for failure to comply.

\section{Conceptual grounding}

I employ an interdisciplinary approach, mobilising analytical tools and concepts from surveillance studies and critical criminology. This work employs theory with caution,

8 E Mykhalovskiy et al, “Callous, Cold and Deliberately Duplicitous': Racialization, Immigration and the Representation of HIV Criminalisation in Canadian Mainstream Newspapers" (CIHR Centre for Social Research in HIV Prevention 2016).

$9 \quad R v$ Mabior 2012 SCC 47 and $R v D C 2012$ SCC 48.

$10 R v$ Mabior, supra, note 9 and $R v D C$, supra, note 9. 
aiming to avoid the objectification of criminalised people for advancing theoretical objectives. As a result, I focus on material experiences of people who have been targets of criminalisation. Such a focus means attending to the varied forms of violence and resulting suffering that criminalised people face in their daily lives. Violence is not an explanatory theory or concept, but rather a material reality faced by people. The aim of the analysis in this article is to denaturalise the violence that is the source of suffering, so violence and suffering are understood not as matters of fate, but as social processes that do not need to be as they are, and are subject to change. To assist with this project, I engage the concepts of legal violence, negative personhood, therapeutic surveillance, and the surveillant assemblage. Examining forms of criminalisation, such a HIV-related criminalisation, with the concept of legal violence can help to understand the relationship between law and violence and how people become targets of violence because they are targets of the law. German Jewish philosopher Walter Benjamin was one of the first to initiate a thread of analysis exploring the relationship between the law and violence. ${ }^{11}$ Benjamin understood violence as inevitable and examined how certain forms of violence are justified and made legitimate by the state, while others are not, and how lines are drawn between the two. Benjamin notes that legal violence is the form of violence enacted by the state; the only official bearer of legitimate violence and the arbiter of legitimate and illegitimate violence. Violence as an instrument needs justification, and that comes from forms of authoritative powers held by the state. ${ }^{12}$ Unjustified violence is intervened in via legal violence, which is manifest as a sanctioned means to limit the autonomy, potential, and capacities of individuals who have offended the laws of the land. Legal violence can put limits on freedom of movement via curfews or forms of incarceration, it can reduce financial freedom via fines and penalties, and it can operate to constrain certain undesirable behaviour via myriad forms of surveillance and coercion.

Legitimate violence held by the state - or legal violence - has the outcome of rendering those who are targets of criminalisation to live lives of civil and social death. They are marked as 'other' and removed from participating in aspects of society granted to citizens. To explore the experiences of the civilly dead, Dayan posed the question, 'What does it mean to live in a negative relation to the law?' To answer the question, Dayan explored a genealogy of negative forms of personhood, such as criminals, slaves, detainees, and animals. Negative forms of personhood are historically constituted through an array of legal processes. People can be denied autonomy, denied freedom of movement, and freedom to participate in civil society. Some are rendered a form of property, a subhuman category, one toward whom it is legal to perform forms of violence. In particular, Dayan undertook a historical genealogy of the non-person made in law and examined how legal processes can constitute the civil death of the nonpersons. Looking back to ancient common law, Dayan noted that there were three principal outcomes of criminality via treason or felony: (1) the forfeiture of property to the sovereign; (2) the corruption of blood, which blocked the descent of property, cutting off inheritance and blood ties; and (3) the extinction of civil rights, resulting in the incapacity to perform any legal function. Blood and property were regarded as

11 W Benjamin, A Critique of Violence (1921).

12 H Arendt, On Violence (1969) p 54. 
metaphors constituting persons in civil society, and thus the corruption of blood and forfeiture of property came to be "operative components of divestment" in personhood. ${ }^{13}$

The legal process that classified a person as a criminal, thus, resulted in the deconstitution of the attributes of their personhood. But what exactly constitutes a person? In the legal context, claims for personhood are often framed as claims for civilly enabled human rights. The language of human rights can be understood as a language of personhood. This language comprises a wide array of social processes, systems, ideas, and tools, including the law and legal frameworks. Many of these things that constitute personhood operate on a theoretical plane above and around the natural biological attributes of the body. Esposito called this infrastructure that enables the attributes of personhood the "dispositif of the person" ${ }^{14}$ This dispositif is what allows humans to become embodied subjects and dispose of their animal selves. The process of "de-animalisation" is what produces subjectivity and the range of social processes, systems, ideas, and tools that makes it possible for the subject to assert forms of freedom, individuality, and self-determination, which thus constitutes the person. ${ }^{15}$ The logical outcome of Esposito's argument is when rendered civilly dead without the legal infrastructure, a person comes to be treated as a non-person, resembling the subhuman, or an animal.

To further explore the experiences of what it means to live as a negative person in relation to HIV criminalisation, I turn to the notion of therapeutic surveillance. ${ }^{16}$ This notion, developed by Canadian critical criminologist Dawn Moore, examines how both benevolent health promotion aims and coercive and punitive regulations can work in concert. This notion was developed as a call to address considerations of the body in surveillance, the body that is watched by others, and to critically address the turn in surveillance studies to consider issues primarily of technology and data-veillance. Therapeutic surveillance as a form of governance is aimed at regulating and constituting a compliant subject through a diffused convergence of information, actors and experts, who are connected to institutions of therapy and the penality. I bring forth this concept as HIV is a medical condition, and there can exist a veil of therapy around the coercive surveillance practices mobilised when HIV is criminalised. This form of surveillance thus relies on human connections to function, and knowledge generated from human interactions is mobilised. The concept of therapeutic surveillance includes a number of key characteristics: (1) the gaze is focused on the individual surveillant subject who is watched by other people; (2) the model relies on the many watching the one, meaning that multiple actors monitor the surveillant subject, including social workers, health professionals, police and lawyers, and even peers who perform a kind of lateral and/or synoptic surveillance; (3) it is personal and is based on intimate details of subject's life, including daily activities, employment, living situation, sex practices, drug taking habits, etc; and (4) the practice is presented under the guise of benevolence, aiming to help the

13 C Dayan, The Law is a White Dog: How Legal Rituals Make and Unmake Persons (Princeton University Press 2011) pp xii.

14 R Esposito, "The Dispositif of the Person" (2012) 8(1) Law, Culture and the Humanities 17.

15 ibid, p 24.

16 D Moore, "The benevolent watch: therapeutic surveillance in drug treatment court" (2011) 15(3) Theoretical Criminology 255. 
problematic individual and "cure the offender of her addictions", while simultaneously benefiting society as a whole. ${ }^{17}$

Such practices of coercion and therapy can be understood as part of the surveillant assemblage, ${ }^{18}$ the varied arrangement of heterogeneous objects, flows of information, entities, institutions, mechanisms and actors that work in concert, divorcing humans from social and territorial settings, to rearrange and reorder bodies into data doubles that are translated and classified relationally depending on the context and purpose. With the surveillant assemblage concept, scholars Haggerty and Ericson were primarily trying to account for the increasing role of technology in surveillance practices. In the assemblage, the watched body can become a hybrid body of data and various forms of knowledge that are captured, ordered, rearranged and reconstructed to render it comparable and calculable, thus enabling strategies of governance, economy and social control. However, considering this theory with therapeutic surveillance, a focus returns to the daily material experiences of bodies under surveillance and towards the people who are subjects of surveillance. When one is rendered a negative person, there can be heightened forms of bodily surveillance, as well as data-veillance, to manage the perceived risks posed to the public. Examining these myriad forms of bodily surveillance is central to the project of examining what it means to live as a negative person under legal regimes.

\section{Methods}

My research is aligned with the historical trajectory of critical social science research, where attention is paid to systems of oppression and the resulting suffering of social actors. The aim of such an approach is to help efforts to contend with suffering as an act supporting action toward forms of emancipation and social change. This means there is an ethical imperative to take a political stance in the work. I employ an interdisciplinary critical ethnographic approach. ${ }^{19}$ Mobilising this approach, I employ the methods from the alternative feminist sociology, institutional ethnography, which enables social research to be developed from the perspective of those who live the problem at hand. ${ }^{20}$ Institutional ethnography practitioners develop knowledge that can help to decentre the dominant ways of knowing, thinking about, documenting, and remembering people. In this case, my ethnography tracks the discourses of the diverse array of institutions engaged with socially organising criminal justice responses to HIV to develop a framework for understanding how criminalised people's daily lives are organised extralocally. ${ }^{21}$ Central to this approach is exploring the disjuncture between people's lived experiences and how they come to be known institutionally. Thus, the approach relies on qualitative interviews with people who are excluded from access to civil and social life, namely those who have faced being criminalised first-hand. ${ }^{22}$ Along with

\footnotetext{
7 ibid, p 265.

18 K Haggerty and R Ericson, "The surveillant assemblage” (2003) 51(4) British Journal of Sociology 605.

19 A Sayer, Method in Social Science: A Realist Approach (Routledge 2009).

20 D Smith, Institutional Ethnography: A Sociology for People (AltaMira Press 2005).

21 V Namaste et al, HIV Prevention and Bisexual Realities (University of Toronto Press 2012).

22 S Reinharz, Feminist Methods in Social Research (Oxford University Press 1992) pp 18-45.
} 
interviews, my approach relied on extensive archival research, as well as ethnographic research within the milieu of activists working to reform criminal justice approaches targeting people living with HIV.

\section{Findings: FOUR LIVES RENDERED LIVED IN A NEGATIVE RELATION TO THE LAW}

In the following section, I detail the experiences of four people ${ }^{23}$ who were criminally charged in relation to HIV non-disclosure in Canada. These are experiences where the outcome of being charged resulted in a flow of information that circumscribed opportunities, rendering them as someone in need of incapacitation, surveillance and retribution. The outcome is a heightened context of penality, comprised of legal and extralegal forms of violence.

\section{Angie}

This first experience comes from my archival research, where, according to media reports, a nurse visited an HIV-positive white woman in her mid-20s from a smaller Canadian town. The nurse was delivering a public health order requiring Angie to disclose her HIV-positive status to all future sex partners. Angie, a single mother, had tested HIV-positive a year earlier. Three years later, the local police arrested Angie, as they had received information from a concerned individual that she was not obeying the regulations imposed under the public health order. Upon her arrest the police stated that her non-compliance with the past public health order was a rationale to release her photograph as a "public safety warning" to the media and community during a televised press conference. The lead detective was quoted in numerous news outlets after the press conference as stating that Angie was "huge threat" to public safety as she had intentions to deliberately have sex with people and not tell them that she had HIV. During the press conference, the police indicated that anyone who had sexual intercourse with Angie should come forward and also seek medical advice. The police noted that they had contact with 10 alleged partners of Angie's whom could state they had unprotected sex with her, and that she had regularly frequented bars and clubs around her town to pick up men. While Angie's privacy was widely breached in the interests of "public safety", the man and others in the case were protected under a publication ban protecting their identities. Angie was released, but given a curfew of 11:00pm to 7:00am. As a result of this release of information, numerous online bulletin boards and discussion forums lit up with posts of the photo and information about the case under headings such as: "Beware of HIV + female rapist", "Girl with HIV having unprotected sex with clubbers", "Lock this whore up", and "Broad has the HIV". In the posts people include identifying details about Angie indicating that they wish to see her punished. It was noted by one media outlet that during a trip to public pool with her young toddler, other pool goers recognised Angie's picture from a newspaper cover. As a result, she was publicly ridiculed and kicked out of the pool with her child. In the end charges of aggravated sexual assault were only laid in relation to sex Angie had with one man. She had met the

23 All names are pseudonyms. 
man and at a later date, they had sex, but the condom broke, and at that time she told him her HIV-positive status. Ultimately Angie pleaded guilty to one charge of aggravated sexual assault and she was sentenced to two years' house arrest, three years' probation, and labelled as a sex offender for life. During a media interview on her case Angie said: "nobody understands what my life is like" and that she did not tell the man about her HIV-positive status straight away because she "got scared". 24

\section{Frank}

After being charged with one count of aggravated sexual assault, Frank, an indigenous man, was fired from his job. While spending time with Frank, he told me his employer found out about his charge due to a social media post. Frank lived in a major Canadian city and was a tall, burly and tattooed man in his mid-40s. He worked as a bouncer in local bars. He told me that his criminal charge was related to a recent relationship with a woman. When he broke up with her, she went to the police. His ex-girlfriend knew his HIV-positive status and she remained HIV-negative, but she was angry about their breakup. Frank had never done anything violent or with intent to harm, but he acknowledged he was a bad communicator and perhaps flirted with other women. He told me how hard it is to date as a straight man living with an HIV diagnosis. Within a few days of the police coming to his door to arrest him, his charge and HIV-positive status were widely disclosed without Frank's consent by people close to the woman who accused him. Frank was harassed through his Facebook account and on a number of online bulletin boards. People called him a rapist who was trying to spread HIV. He had to close his online accounts. His close friends sided with the woman after finding out he had HIV. Frank lost his social network in the material and digital worlds. He became alienated and had no way to challenge his charge in the public sphere. The aggravated sexual assault charge, loss of his job and his social world caused him to have a mental breakdown. He had been living hand-to-mouth, and after losing his job, he then lost his housing. He was in a deep depression and ultimately ended up living out of a McDonald's bathroom for over a month. The mark of accusation alone caused Frank's entire reality to be drastically altered for the worse. He was still awaiting trial when I last saw him.

\section{Shaun}

The impact of heightened penality, legal and extralegal, extends well beyond prosecution, if there is a prosecution. A Black man I spent time with and interviewed, who was in his mid-20s, told me about the violence he faced while in jail, and also in his neighbourhood, after information about him being charged was circulated. Shaun worked in a factory in the suburbs of a large urban centre and lived in a low-income high rise block. He loved his dog and took her for walks regularly. He found out he was charged with aggravated sexual assault when the police called him. He turned himself in immediately, with his uncle, so that the police would know he was not a risk and he could

24 K Conner, "Woman with HIV gets house arrest: Didn't disclose her status to sex partner" Sun Media (20 November 2009); B Powell, "Woman with HIV charged after sex" Toronto Star (23 March 2007) B.4. 
be granted bail. At the police station he was asked to enter an interrogation room, and was beaten by the police. When he asked for them to stop, the officers referred to him being a rapist with HIV. He was then taken to another interrogation room where he was told that nothing had happened, and that he must have been mistaken about his assault. His charge was related to his ex-girlfriend who had gone to police after she and Shaun had fought. She immediately tried to withdraw her charge, but a charge of aggravated sexual assault is considered in the public interest for prosecution to pursue. She remained HIV-negative, and he was virally undetectable, rendering him non-infectious. Shaun was denied bail; the judge said it was due to the seriousness of the charge. He had no previous criminal record. A number of media articles were published with Shaun's name, his biometric details, including height, weight, eye and hair colour, any visible identifying marks, a photograph, and a statement asking for anyone who had sex with him to come forward, due to the police releasing a public safety warning. He spent multiple years under house arrest, but ended up incarcerated for over six months because his surety (the person tasked with vouching for him under pre-trail detention in the community) stopped supporting him.

While incarcerated he was placed in general population with a random collection of men facing all types of charges. He started facing harassment. Prisoners made comments about him being a rapist, and asked why he took medication. Ultimately, after days of harassment he was brutally assaulted by other prisoners. They said they knew he was trying to spread the virus. Shaun was certain that guards had leaked information about his charge to the prisoners, knowing he would be assaulted. Under an institutional directive, prisoners' charges and health status are supposed to remain confidential and the only people with access to the information are guards. Access to information from the outside world was severely limited and Shaun felt there was no other way for the information to end up in the hands of prisoners. He spent the last part of his pre-trial remand in administrative segregation, which is 23.5 hours a day locked alone in a cell. His case had not even gone to trial. A month later his charges were dropped and he was released. Upon release he ended up in his current apartment in a suburban high rise building. One day while walking his dog a group of guys from his neighbourhood approached him. They started saying that he should leave the neighbourhood because he was known to have spread HIV. They started pushing him around. They had seen articles about him in the newspaper. He told them he was virally undetectable - something the newspaper never reported - and that it was impossible for him to transmit HIV to anyone. This group of men beat him up regardless.

\section{Joseph}

Lastly, a white man in his early 40s, who I spent time with and interviewed, had recently come out of three years of pre-trial house arrest. His charges were ultimately dropped, as his case only involved oral sex with another man. No HIV transmission was alleged in the case; he was charged in relation to the act of non-disclosure. Under house arrest, Joseph lived in the houses of different sureties who vouched for him. He was reliant on the sureties, and he could not work, or go to school, and was severely isolated. He went into a deep depression. As part of his condition he was told to present himself with any 
future sex partners to the police 24 hours in advance of the sex act. The person was supposed to indicate their consent at the police station. This was an exceptional condition that made him angry. On top of his charge he also received a public health order, which included a requirement for a public health nurse to visit him regularly for counselling. The counselling made him feel pathologised and bad. He had information about safer sex from a local AIDS organisation, and he used that information with his partners. The public health counselling was promoting practices that were unnecessary, such as using a condom for oral sex. He was virally undetectable and not able to transmit the virus. Despite this, the nurse treated him as though he was highly contagious and dangerous. He had also been barred from using social media or any dating and hook-up apps. Once the charges were finally dropped, Joseph went to find his own housing. His case had been reported in the media, including details about his HIV-positive status, biometric details and other identifiers. Despite his charge being dropped, Joseph's name, HIV-positive status, and charge of aggravated sexual assault came up easily in Google searches. Joseph told me that while reporters were eager to cover his case when charges were applied, none were interested when they were dropped. No articles were written about his vindication in court. When applying for one apartment, the landlord asked him to come to visit the place. A good sign Joseph thought. When he showed up the landlord opened the door and yelled at him "I don't rent to rapists" and then pushed Joseph down a flight of stairs. Joseph was also denied jobs. After looking for employment for months, he finally found one he though was the right fit, so he applied. A few days later, he got a message back from the potential employer. The message said his past charge of aggravated sexual assault might make other employees in the office uncomfortable, so despite him having the right expertise, they decided not to hire him.

\section{ANALYSIS AND DISCUSSION}

The material impacts of criminalisation come in the form of physical and psychological violence, as well as shunning, social exclusion, loss of autonomy, and the means to realise safety and security. Angie was treated as a heightened risk to public safety due to an initial public health order. Her case was hyped up with police claiming ten complaints against her during an unprecedented press conference, identifying her to the media and community as a "huge threat" to public safety. She was harassed online due to the dispersal of the police information on her case, called a "whore" and then publicly shunned in her own community. Shaun's ex-girlfriend learned that she could go to the police because of a conversation she and Shaun had in a clinical setting with a public health official. His ex-girlfriend's angry and untrue statement to police was used to institutionally construct Shaun's intent to cause harm - as encouraged by public health authorities. Shaun was beaten by police, he faced breaches of privacy while incarcerated, with his charges and health information leaked, and was then assaulted in his neighbourhood because his HIV-positive status and criminal charges had been publicised. As a result of media depictions of his case, he lost autonomy, privacy, and the ability to realise his safety in his own community. Once information about Frank's criminal charges went public, he lost his job, along with his social network and supports. As a result of the stigma associated with criminality and his HIV-positive status he lost 
his social support network, leading to him having an emotional and psychological breakdown, unable to garner the means to realise his own safety and security. The dispersal of media representations on Joseph's criminal case meant he too was unable to access the physical, psychological and economic safety and security to which legal persons were entitled. Due to how HIV had been constructed as a risk by the public health team, externally from his own experience, Joseph was counselled to view his sexuality as a pathology, and also came to be under heightened surveillance controlling the details of his sex life. These experiences outline how intersecting flows of information, in the form of media articles, personal health records, police communications, social media posts, public health procedures - all forms of information developed extralocally from the actual lives of people - result in a context of amplified formal and informal penality.

In the following sections, I briefly return to my conceptual grounding, addressing the concepts of negative personhood, legal violence, the therapeutic surveillance, but first, I address these experiences through the lens of the surveillant assemblage, which helps to explore how multiple forms of violence are intertwined and constitutive of each other. These concepts help to denaturalise the violence of criminalisation and the resulting suffering of those rendered to live lives in a negative relation to the law. The intersection of information flows that emerge as a result of a charge in relation to alleged HIV nondisclosure makes possible a range of legal and bureaucratic punishments, including some of the most severe and harsh that are sanctioned, along with a range of personal forms of stigma, discrimination, and retributive punishment. The amplification of penality that manifests means that mechanisms usually reserved as exceptions can easily become the rule: exceptions such as the police releasing a photo to the public before prosecution for reasons of public safety, denying people bail even when they have no criminal record, and placing people under conditions of solitary confinement for reasons of security. These exceptions can come to be the norm in cases of HIV non-disclosure and exposure. While they are considered legal, some are contested and in a grey area, such as the use of administrative segregation and pre-trial detention. ${ }^{25}$

Along with these amplified forms of formal legal punishment come a range of informal forms of extralegal punishment, discrimination, and violent retribution connected to flows of information, such as the media exposing private photographs and details about people so that they become publicly recognisable in their communities, social media and online bulletin board posts disclosing information and charges asking the community to "watch out" for those charged, with the result that people are barred from public services, are denied housing and lose employment. Additionally, as a result of how information about charges is dispersed, people face a wide range of physically and emotionally violent consequences, such as beatings and verbal abuse. These amplified legal and extralegal forms of penality begin as soon as the charges are applied and do not relate to a guilty verdict: people who are accused can be treated as guilty before proven innocent.

25 For example, see L Kerr, "The origins of unlawful prison policies" (2015) 4(1) Canadian Journal of Human Rights, and A Deshman, "Set Up to Fail: Bail and the Revolving Door of Pre-trial Detention" (Canadian Civil Liberties Association and Education Trust 2014). 
The concept of the assemblage is also helpful for exploring how public health legislation works in concert to enable other legal processes. Public health practices and laws form part of this diverse assemblage of technologies of surveillance and governance, which includes the criminal justice system, that interact with and reinforce one another. Public health orders were used to help increase someone's understood level of risk in the eyes of the criminal justice system. Public health legislation therefore cannot be understood as easily divorced from other components of this apparatus, or as a form of jurisprudence that can be applied in a silo.

\section{Civil and social death}

The experiences of Frank, Angie, Shaun and Joseph, are those of civil and social death, of negative personhood, in each case constituted through law, but with harsh and violent legal and extralegal consequences. The enactment of legal forms of violence bring about a whole array of extralegal violence - interpersonal, casual, informal, and institutional that is not necessarily legal, but is enabled through legal processes because the people onto which it is enacted have been deemed less than legal persons and no longer in need of protection. As with Dayan's analysis of ancient common law, living in a negative relation to the law results in a forfeiture of rights to property and engagement in civil life - a loss of access to safety, bodily autonomy, and economic security. And while the notion of corruption of the blood is no longer one that exists in the law (as people are not blocked from inheritance if they break laws) these cases reveal a whole other sort of corruption of the blood, one where ideological fears of a bodily virus - regardless of one's level if infectiousness - results in violent consequences.

When returning to the notion of negative personhood it is important to note that Esposito's conceptualisation of the dispositif presents a trap, one that it is inherent in liberal forms of politics. Through the production of personhood, the negative is also produced: the non-person or animal. Legal tools, through defining positive personhood, result in also defining the opposite. Frank, Angie, Shaun and Joseph have had their personhood revoked for the protection of the public. In defining the human rights of certain subjects, rights language continually negatively constitutes non-rights. As Esposito noted, "the person not only includes its own proper negative within it, but constantly reproduces the negative". ${ }^{26}$ Inherent in the notion of a person is the nonperson, when a subject becomes less of a person and their access to self-determination and autonomy are taken away. Forms of liberal politics that emerge from this process are, for example, the safeguarding of rights of certain persons that are predicated on the suspension of rights of others. The suspension of rights to personhood for the risky, guilty, and criminal are justified to uphold the rights and protections of the innocent and victimised. The citizen has access to civil life as a protected person, while the non-citizen lives in precarity and is civilly dead. This is an unresolvable conflict and inherent problem within liberalism. In the context of the criminalisation of HIV, this means that the safety and security of legal persons is preserved at the expense of the rights of the criminalised. Joseph was denied a job and housing. The safety of his potential landlord

26 Esposito, supra, note 14, p 24. 
and employer were predicated on the loss of Joseph's economic security and physical safety. Angie's community shunned her for their own perceived protection, at the expense of her autonomy and freedom. Frank was fired from his job and shunned from his material and digital community for the protection of his ex-girlfriend. Shaun was beaten up by his neighbours, told to move from the area, due to their fear of perceived infection. These experiences, among many others, highlight that living in a negative relation to the law means the safety and security of legal persons is protected over the rights of the criminalised subject of risk. Seeking to redress the violence faced by negative persons may mean putting into question the liberal notion of personhood altogether.

\section{Therapeutic and retributive surveillance}

These individuals came under heightened forms of surveillance, both coercive and therapeutic, with violent and retributive consequences. Surveillance targeted their bodies, and was not just attuned to forms of data in the cloud. Because HIV is a medical condition, there can exist a veil of therapy around the coercive surveillance practices facing people who are criminally charged, such as with Joseph who was monitored by a nurse and the police regarding his sex life, under the guise of therapy, but driven by a logic of fear and risk management that was warped from the reality of his actual experience and the science regarding infectiousness.

While addressing how coercive and therapeutic surveillance becomes intertwined, Moore outlines how under a gaze of therapeutic surveillance the targeted individual is watched by others; the many watch the one, via lateral and synoptic surveillance from institutional actors, as well as by peers. ${ }^{27}$ In cases of HIV criminalisation, whether this involves nurses, police, officers of penal institutions, or members of the public who engage in online chat-room forums or community members attending a public pool, the diffusion of information across a variety of actors in society to watch the marked surveillant subject is activated in both the therapeutic and coercive senses. Institutional forms of surveillance are omnipotent and able to target the criminalised subject at any point, while forms of lateral surveillance from neighbours, potential employers, or others in the communities of the criminalised subject, come to be enacted and socially activated when the non-person seeks engagement in the social and civil realm of legal persons. In the context of the four cases explored in this article, these forms of surveillance are intertwined and presuppose each other. Angie was put under a curfew, and she also experienced limits on her access to public space due to the dispersal of media coverage. Joseph was denied access to housing and employment due to his information being available online. Shaun was confined to a cell for 23.5 hours a day after being assaulted by his peers in prison, and also assaulted in his community due to the exposure of his identity in the media: all of these individuals, targets watched by many, their every move tracked by institutions, or confronted by people in their communities, with potential violent consequences.

27 Moore, supra, note 16 
Moore developed the concept of therapeutic surveillance when examining people who were mandated to attend drug treatment courts, and thus the main focus of this concept is on clinical and institutional encounters that individuals face, as well as surveillance by peers. The concept does not, however, account for the forms of physical violence and retribution that are the result in cases of HIV criminalisation. So, while, some forms of surveillance were enacted under the guise of therapy (namely those that were institutional), other forms of surveillance, specifically lateral forms, enacted by legal persons in the communities of the criminalised, were primarily comprised of forms of personal violence, resulting from fears of contamination and populist retribution.

Furthermore, Moore notes that the forms of surveillance enacted were based on intimate details of the subject's life. When someone is charged in relation to HIV, highly personally information about the subject, including biometrics, details of their sex lives, to medical information, viral infectiousness and adherence to anti-HIV medications become public. From Facebook posts, police press releases, bulletin board posts, word of mouth, media articles and health data, forms of information come to be mobilised in the service of punishment to help incapacitate and circumscribe people's lives. Through the circulation of people's images and biometric details in the media, individual citizens enact forms of lateral surveillance; vigilante retribution and punishment, where people inform on their sex partners, and neighbours seek to rid their communities of risks and punish perceived wrong-doers.

\section{Big data?}

This article is included in a journal special issue on big data and risk regulation. How does it fit? Well, it may be disputed that the analysis within this article constitutes something related to the study of big data altogether. In general terms, within surveillance studies, examinations of big data focus on issues related to the aggregation of data and the meta. Concerns with big data are often about being watched from afar based on forms of data-veillance and data doubles held in the cloud. Authors in this journal have already discussed the complexities of managing the risks associated with big data to individuals, ${ }^{28}$ and the paternalism of medical authority as it manifests in health laws. ${ }^{29}$ What my article adds to the debate over big data is a turn of attention away from the meta, towards the micro, to the body, where my analysis is attuned to the myriad ways in which data that has been collected on certain classified individuals can be mobilised in concert to organise and circumscribe certain people's lives. Here, the analysis seeks to examine how people classified institutionally as risky are targeted and marked within a range of networks of information for the purposes of social control. This analysis shifts attention away from notions of the general public, population and aggregates, towards specific targeted and classified individual bodies. The collect it all NSA style of data sweeping is often presented as negative as it breaches the privacy of innocent people who have done nothing wrong. This focus on innocence can inadvertently reinforce the notion that those marked as not innocent, or as risky, or a

\footnotetext{
28 A Spina, "Risk Regulation of Big Data: Has the Time Arrived for a Paradigm Shift in EU Data Protection Law?" (2014) 5(2) EJRR 248.

29 F Simões, "Paternalism and Health Law: Legal Promotion of a Healthy Lifestyle" (2013) 4(3) EJRR 347.
} 
criminal, or guilty, should have these forms of technology mobilised against them. An innocent versus guilty dichotomy is reinforced, where state-defined categories of offender, crime and victim are uninterrogated and followed in accordance with meanings provided by the state and in legal processes. I am hoping to step beyond the dichotomous narratives provided through legal discourse - where I am not interested in presenting innocent subjects in contrast to the guilty mark of institutions. Rather, I want to understand the materiality of being marked as a criminal and a risk to public safety, and the role that diverse forms of information play in constituting criminality.

\section{Conclusion}

This critical ethnographic inquiry functions as an act of bearing witness to suffering from violence - both institutional and interpersonal, and enabled and activated through a complex range of forms of information and practices. Focusing on the daily lives of people who face criminalisation first hand - the analytical frame of living in a negative relation to the law - moves analysis beyond a solely theoretical object of inquiry. From this perspective, people can be disarticulated from their labelled narrative of criminality, and instead attention is paid to the microphysics and material consequences of legal and extralegal violence. Social research from the perspective of the civilly and socially dead helps elaborate the trap presented under liberal notions of personhood, where further forms of liberal legal protections may need to be re-evaluated. The analysis within this article attends to the material, violent impacts of criminalisation; violence - legal and extralegal - that is enhanced and amplified through the convergence and flow of information. This assemblage of data-mediated risk management practices and effects can result in similar kinds of discriminatory effects to those within some big data surveillance systems. This critique contributes toward challenging the administration of punishment in society, to bear witness and call for action, and to form the political basis of life worth living for those who are rendered civilly and socially dead under legal regimes. 